\title{
The use of active edible coatings made from a combination of Lepidium sativum gum and Carvacrol to increase shelf life of farmed shrimp kept under refrigerator condition
}

\author{
M Karamkhani ${ }^{1}$, S. A. A Anvar ${ }^{2 *}$, M Ataee $^{2}$ \\ ${ }^{1}$ Department of food science and technology, Faculty of agriculture, Science and research branch, Islamic Azad \\ University, Tehran, Iran \\ ${ }^{2}$ Department of Food hygiene, Science and Research branch, Islamic Azad University, Tehran, Iran
}

Received: August 2018

Accepted: November 2018

\begin{abstract}
The aim of this study was to evaluate the effect of edible coating based on Lepidium sativum seed gum containing different levels of carvacrol on microbial, physical quality and shelf life of farmed shrimp (Penaeus semisulcatus) during refrigerated storage (18 days). At first, different concentrations of carvacrol $(0,5,10$ and $15 \%)$ were added to edible coating. After that the color indexes, antioxidant and antimicrobial activities of coating samples were studied. Then the shrimp samples were covered with these coating solutions, and were evaluated the effects of them on samples quality and shelf life. The obtained results from edible coating tests showed that by increasing the carvacrol in edible coating, the antioxidant activity and $\mathrm{L}^{*}$ values of samples were increased significantly, conversely, the $b^{*}$ value significantly was decreased $(p<0.05)$. Microbial analysis of shrimp samples indicated that edible coating containing $10 \%$ and $15 \%$ carvacrol had significant effects on reducing

The smallest changes in $\mathrm{pH}$ and TBA amounts were seen in the coating samples enriched with $10 \%$ and $15 \%$ carvacrol. Using of coating containing different levels of carvacrol was increased $L^{*}$ and $a^{*}$ values while the $b^{*}$ significantly was decreased $(p<0.05)$. The results stated that the application of edible coating enriched with carvacrol significantly improved sensory quality of samples $(p<0.05)$. It has been confirmed that coating the shrimps with cress seed coating containing $10 \%$ and $15 \%$ carvacrol retarded the melanosis in shrimp samples. This study thus clearly indicated the effect of cress seed gum coating containing carvacrol on shrimp samples improved their good quality characteristics and the shelf life during refrigerated storage, which was supported by the results of microbiological, chemical, and sensorial properties. The shrimp treated with cress seed gum coating containing $10 \%$ carvacrol gave a good sensory quality.
\end{abstract} microbial load $(p<0.05)$.

"Correspondence S.A.A Anvar, Department of Food hygiene, Science and Research branch, Islamic Azad University, Tehran, Iran (e-mail: saaa4824@gmail.com).

Keywords: Shrimp, Carvacrol, Lepidium sativum seed gum, Edible coating, Shelf life, microbial load 


\section{Introduction}

Safety and organoleptic properties of food materials change due to reactions such as microbial decay and oxidation. These reactions reduce the nutritional values of products because they destroy their useful constituents (essential fatty acids, vitamins and proteins). The disorders cause undesirable flavor and diseases in humans in result of their consumption (Sanches-Silva, Costa, Albuquerque, Buonocore, Ramos, Castilho, Machado, \& Costa 2014). The new demands of consumers and international markets, changes have taken place in the distribution of food materials and in retail systems that increase shelf life and make it possible to transport products over longer distances. Therefore, it can be expressed that increasing shelf life of decayable food materials is one of the biggest challenges in the industry of packaging foodstuffs faces (Vermeiren, Devlieghere, van Beest, de Kruijf \& Debevere 1999; Seyfzadeh, Motalebi, Kakoolaki, \& Gholipour, 2013)

The food industry has introduced a new packaging system called active packaging to improve packaging food materials and preserve the quality and freshness of decayable foodstuffs (Sung, Sin, Tee, Bee, Rahmat \& Rahman 2014). Therefore, edible and biodegradable coatings and films containing antimicrobial and antioxidant compounds have attracted interest in recent years as alternatives for preserving food materials. Active materials are compounds that increase shelf life of foodstuffs, improve storage conditions of food materials, and preserve them. These compounds are divided into natural and synthetic groups. Considering the awareness of consumers of the problems caused by synthetic compounds for human health, and so there are consumer demand for use of natural compounds (Bahram, Rezaei, Soltani, Kamali, Ojagh \& Abdollahi 2012), substances like essential oils and extracts and other active ingredients obtained from plants have been suggested as suitable alternatives for improving the shelf life of decayable food materials (Sacchetti, Maietti, Muzzoli, Scaglianti, Manfredini, Radice \& Bruni 2005).

Shrimp as one of the most important seafoods having high economic and nutritional values in many places throughout the world, it is a decayable product that has a short shelf life, and improvement of its shelf life is important for producers and consumers (Wang, 2014). Shrimp shelf life and safety during storing in refrigerators and catching it greatly depend on enzymatic and microbial changes. Shrimp meat remains active after dying and is biochemically changes. Organic decomposition or changes in compounds found in shrimps may take place by various factors like enzymes, oxidation, and microbial activities. Methods that are used for storing shrimps must prevent oxidation and also biochemical activities of enzymes (MoosaviNasab, Moosavi-Nasab, Mesbahi, Jamalian \& Maghsoudlou 2014). Essential oils and compounds obtained from plants are natural antimicrobial compounds used in food materials. It seems that use of natural products like antimicrobial compounds is an interesting 
method for controlling bacterial pathogens and for increasing shelf life of processed foodstuffs in order to decrease health risks. Moreover, a group of consumers would like to consume natural foodstuffs free of chemical additives and of microbes in packages made of eco-friendly materials (Rodrigues, Carvalho, Souza, Oliveira, Franco, Schaffner, Souza \& Magnani 2017; Kuorwel, Carn, Sonneveld, Miltz \& Bigger 2011). It has been reported that the antimicrobial effect of plant essential oils is due to the presence of phenolic compounds called Terpenoids that are active against a broad spectrum of microorganisms. The most important members of this group are Carvacrol and Thymol although there are also other compounds like Linalool, Linalyl acetate, Citronellal, Piperitone, and Menthol in this group. Antimicrobial activities of most terpenoids are related to their functional groups, and it has been proved that the hydroxyl group of phenolic terpenoids and presence of delocalized electrons are important for their antimicrobial effect (Hyldgaard, Mygind \& Meyer 2012).

In recent decades, antimicrobial active packaging has been widely studied. Use of this method can improve safety of food materials, inhibit pathogenic bacteria, and control decay of foodstuffs by using the minimal amount of active compounds (Tang, Lu, Li, Zhou, Xie \& Zhang 2013). The present research intended to study the use of edible coatings prepared from hydrocolloids of garden cress seeds. These coatings contain carvacrol as a natural preservative with antimicrobial and antioxidant properties. They can be used as a suitable way of preserving shrimp quality during the storage period.

\section{Materials and Methods}

\section{Preparation and extraction of Cress Seed Gum (CSG)}

The garden cress seeds (L. sativum) was purchased from the Seed and Plant Improvement Institute of Karaj (Karaj, Iran). In first step, the cress seeds were sifted to remove all forreign matter such as dust, stones, chaff, immature and broken seeds. Then, was washed in three times with its triple weight of ethanol $96 \%$ for 15 minutes to remove the turbidity and contamination. After that the seeds were drying in an oven at $45^{\circ} \mathrm{C}$ for $2 \mathrm{~h}$. Then the seeds were mixed with distilled water (distilled water: seed of $30: 1$ ) at $45^{\circ} \mathrm{C}$ for $30 \mathrm{~min}$ using a magnetic stirrer (1100 rpm) until the gum was achieved and placed in water. The gum was separated from the seeds and dried in an air oven at $45^{\circ}$ C for 18 h (Jouki, Khazaei, Ghasemlou \& HadiNezhad 2013).

\section{Preparation of different edible coatings of CSG}

The amount of seed needed to prepare the coating composition solutions was determined based on the percentage of gum extracted from the seeds. For preparing the active coatings, the solutions of the plasticizer and emulsifiers (Rowaflex x570, Switzerland) made to a suitable concentration of dry matter (dry gum in the coating solution) and carvacrol with different concentrations of $0,5,10$ and $15(\mathrm{w} / \mathrm{w}$ $\%$ ) were added under constant stirring conditions. To obtain the emulsion, the resulting mixture was homogenized using a 
homogenizer (ULTRA-TURRAX, Germany). (Jouki et al., 2013).

\section{Experiments of various coatings}

\section{Color measurment}

The color of the coatings was determined by using a Hunter Lab colorimeter (Hunter Lab, Color Flex, USA). The parameters measured are L* (Lightness-Brightness), a* (RednessGreenness) and $\quad \mathrm{b}^{*} \quad$ (YellownessBlueness) (Mohebi \& Shahbazi 2017).

\section{Measuring antioxidant activity}

The radical scavenging activity of active coatings was determined using the stable radical 2,2 diphenyl-1-picrylhydrazyl (DPPH) on basis of bleaching of the bluish-red or purple-colored methanol solution of DPPH as a reagent. Absorbing the solutions was read against pure methanol at $517 \mathrm{~nm}$ by using a Perkin-Elmer spectrophotometer (Ultrospec 2000, Pharmacia Biotech Inc., USA) and the percentage of DPPH radical-scavenging activity was measured using the following equation: (Haddar, Sellimi, Ghannouchi, Alvarez, Nasri \& Bougatef 2012).

Scavenging Activity (\%) $=\left(1-\frac{\text { Absorption sample }}{\text { Absorption DPPH }}\right) \times 100$

\section{Determine antimicrobial activity}

The antimicrobial activity of the edible coatings was investigated using the disk diffusion method against 5 microorganisms that including Lactobacillus plantarum, Pseudomonas aeruginosa, Salmonella typhimurium, Staphylococcus aureus, Escherichia coli. Some of these bacteria are common food borne pathogens and some of them are spoilage bacteria listed. After preparing the culture medium and activation of the examined microorganisms, Disks $(6 \mathrm{~mm}$ diameter) were cuted from the coatings and were placed on the inoculated culture medium.Then, the antimicrobial activity was measured by the diameter of inhibition zone (Gimenez, Gomez-Guillen, Lopez-Caballero, Gomez-Estaca \& Montero 2012 ).

\section{Shrimp Coating and Storage in the Refrigerator} After purchasing the shrimps (Penaeus semisulcatus) were randomly divided in 5 treatment groups, namely: No Carvacrol or edible coating was used in T0 (Control), Coatings with no Carvacrol but edible coating (T1), $5 \%$ of Carvacrol (T2),10\% of Carvacrol (T3), $15 \%$ of Carvacrol (T4). The shrimps were immersed in each concentration of coating solution for 30s and the coating solution was applied uniformly on the whole surface, while control shrimp were dipped in purified water. After coating process, all of the samples were dried in the oven at $25^{\circ} \mathrm{C}$ for $5 \mathrm{~h}$ (Khazaei, Esmaiili \& Emam Djomeh 2016). The effect of active coatings on the quality of kept shrimp was studied at $4{ }^{\circ} \mathrm{C}$ for 18 days and appropriate experiments were carried out on all samples at 6 days intervals.

\section{Experiments of shrimp samples}

\section{Microbiological analysis}

For microbial tests, $25 \mathrm{~g}$ of shrimp sample was added to $225 \mathrm{ml}$ of $0.1 \%$ buffer peptone water (BPW; Merck, Darmstadt, Germany) and then homogenized in the Seward Stomacher 400 range. Ten-fold serial dilution was prepared in $0.1 \%$ peptone water (up to $10^{6}$ dilutions), and then $0.1 \mathrm{ml}$ aliquots from each dilution was 
spread in duplicate on agar culture media. For count the Total Bacteria count were used from Plate Count Agar (PCA) medium with incubation at $30^{\circ} \mathrm{C}$ for $48 \mathrm{~h}$, while to enumerate the psychrophilic bacteria at $7{ }^{\circ} \mathrm{C}$ for 10 days on the same medium (Shahbazi, Shavisi \& Mohebi 2016 ).

\section{Chemical analyses}

\section{pH Measurement}

The $\mathrm{pH}$ values of the samples were measured using a digital $\mathrm{pH}$-meter (pH-Meter E520, Metrohm Herisau, Switzerland) according to the method described by the National Iranian Standard No. 2852 (ISIRI, 2007).

Measuring the Thiobarbituric Acid Index (TBA)

Thiobarbituric acid (TBA) is an organic compound which is used as reagent in assaying malondialdehyde to present oxidative reactions. Measurement of TBA was done using the method of AOCS Cd 19-90 (AOCS, 1998). Initially, $200 \mathrm{mg}$ of the oil sample into a volumetric flask $25 \mathrm{ml}$ and was dissolved it in a small volume of 1-butanol and make up to volume, then completely mixed with a magnetic stirrer. Five $\mathrm{ml}$ of the sample solution mixed with $5 \mathrm{ml}$ Thiobarbituric Acid Reagent (The TBA reagent was prepared by dissolving $200 \mathrm{mg}$ 2-thiobarbituric in $100 \mathrm{ml} \mathrm{1-butanol}$ ) and incubated for $2 \mathrm{~h}$ in a $95{ }^{\circ} \mathrm{C}$ adjusted water bath and cooled for 10 min under tap water. The absorption was measured at $530 \mathrm{~nm}$ compared with a corresponding blank by spectrophotometer (Ultrospec 2000, Pharmacia Biotech Inc., USA) (including solvent and reactant solution) (Nirmal \& Benjakul,
2009). Results obtained were calculated using the following equation:

$$
T B A \text { value }=\frac{50 \times(A-B)}{m}
$$

Where $\mathrm{A}$ is the absorbance of the test solution, $\mathrm{B}$ is the absorbance of the reagent blank and $\mathrm{m}$ is the mass in $\mathrm{mg}$, of the test portion.

\section{Physical analyses}

\section{Texture analysis}

The textural analysis of shrimp specimens was carried out using a texture analyzer Instron universal testing machine (Instron Corporation, Rochdale, England) and the penetration test with probe rod $(6 \mathrm{~mm}$ diameter probe). For textural analysis, segment of abdominal musculature of shrimp was selected and the hardness of the tissue samples was determined at room temperature. A two stage compression cycle was used to create $30 \%$ of their initial height compression. The speed of the probe movement was $1 \mathrm{~mm} \mathrm{~s}^{-1}$ (Aminifar \& Emamjome 2014).

\section{Color measurment}

The color indexes of shrimp samples $\left(\mathrm{L}^{*}=\right.$ lightness or brightness, $\mathrm{a}^{*}=$ redness, $\mathrm{b}^{*}=$ yellowness) was determined by using a colorimeter Minolta (Minolta CR300 Series, Minolta Camera Co. Ltd., Osaka, Japan). Color measurements were carried out directly on fresh and coated shrimp samples as well as on all experiment days (days 1, 6, 12 and 18) (Ghorbani Maghsoudlou, Aalami, Ghorbani \& Sadeghi 2016).

\section{Sensory analysis}

The sensory attributes of shrimp were performed by eight-members of experienced in 
the evaluation of meat and marine products according to ISO 8586. They trained using discriminative tests with practice evaluation methods of determining spoilage characteristics in shrimp. The panelists were asked to assess color, odor, texture and overall acceptability of un-inoculated shrimp samples using a nine descriptive hedonic scale (9 being the highest quality score and 1 the lowest). A score of 5 sensory acceptability was takenas the average score for minimum acceptability. Samples were randomly placed into plates of disposable containers, these plates were colorless and odorless and labeled with random numbers of 3 digits. The evaluators simultaneously and individually evaluated samples under fluorescence of moonlight and sunshine (similar to daylight) and at ambient temperature (Mohebbi \& Shahbazi 2017).

\section{Evaluation of Melanosis phenomenon of shrimp samples}

Melanosis of shrimp were performed by 8 panelists of experienced in the evaluation of meat and marine products. Melanosis (manifested as black spots on the shell, especially on the head) was assessed according to a visual scale from 1 to 4 , in which $1=$ complete absence of black spots; $2=$ a few small spots on the carapace; $3=$ considerable spotting on the carapace; 4 = substantial spotting over the entire shrimp. (Montero, Martinez-Alvarez, \& Gomez- Guillen 2004).

\section{Statistical analysis of data}

Data were intially evaluated by analysis of variance (ANOVA) in a completely randomized design with factorial arrangement, and comparison of the mean values was done using Duncan's multiple range test at $\alpha=5 \%$ probability level. Microsoft Windows Excel 2013 and SPSS software (Version 22.0 for windows, SPSS Inc., Chicago, IL, USA) were used to analyze the resulting data.

\section{Results}

\section{Color indexes of edible coatings}

The results of statistical analysis showed that the $L^{*}$ (lightness-brightness) and $b^{*}$ (yellownessblueness) values of the color of the edible coatings based on $L$. sativum gum were significantly influenced by the treatments $(p<0.05)$. However, in the $\mathrm{a}^{*}$ (redness-greenness) value there was no statistically significant difference between various treatments $(p>0.05)$ (Table1).

Table 1. Comparison of the mean values of the color indexes $\left(\mathrm{L}^{*}, \mathrm{a}^{*}, \mathrm{~b}^{*}\right)$ with various edible coatings based on $L$. sativum gum

\begin{tabular}{llll}
\hline Treatments & $\mathbf{L}^{*}$ & $\mathbf{a}^{*}$ & $\mathbf{b}^{*}$ \\
\hline T0 & $86.39 \pm 041^{\mathrm{c}}$ & $-1.19 \pm 0.44^{\mathrm{a}}$ & $2.88 \pm 0.81^{\mathrm{a}}$ \\
T1 & $88.65 \pm 0.78^{\mathrm{a}}$ & $-1.97 \pm 0.56^{\mathrm{a}}$ & $-0.00 \pm 0.8^{\mathrm{b}}$ \\
T2 & $87.83 \pm 0.35^{\mathrm{b}}$ & $-1.24 \pm 0.36^{\mathrm{a}}$ & $-0.11 \pm 0.07^{\mathrm{b}}$ \\
T3 & $89.05 \pm 0.14^{\mathrm{a}}$ & $-2.27 \pm 0.52^{\mathrm{a}}$ & $-0.98 \pm 0.04^{\mathrm{c}}$ \\
\hline
\end{tabular}

Coatings with 5\% of Carvacrol (T1), 10\% of Carvacrol (T2), 15\% of Carvacrol (T3). No Carvacrol was used in T0 (Control). L: Intensity of color lightness, a: redness-greenness, b: yellowness- blueness. In each column, similar letters indicate that there is no significant difference between the values at the probability level of 05 .

\section{Antioxidant activity of edible coatings}

The results of statistical analysis of the data showed that the treatment had a significant effect on the amount of DPPH free radical inhibition of shrimp samples with various 
edible coatings based on $L$. sativum gum $(p<0.05)$. As shown in Fig. 1, the free radical inhibition DPPH content of samples increased significantly with the addition of carvacrol to the edible coating and increasing its level $(p<0.05)$.

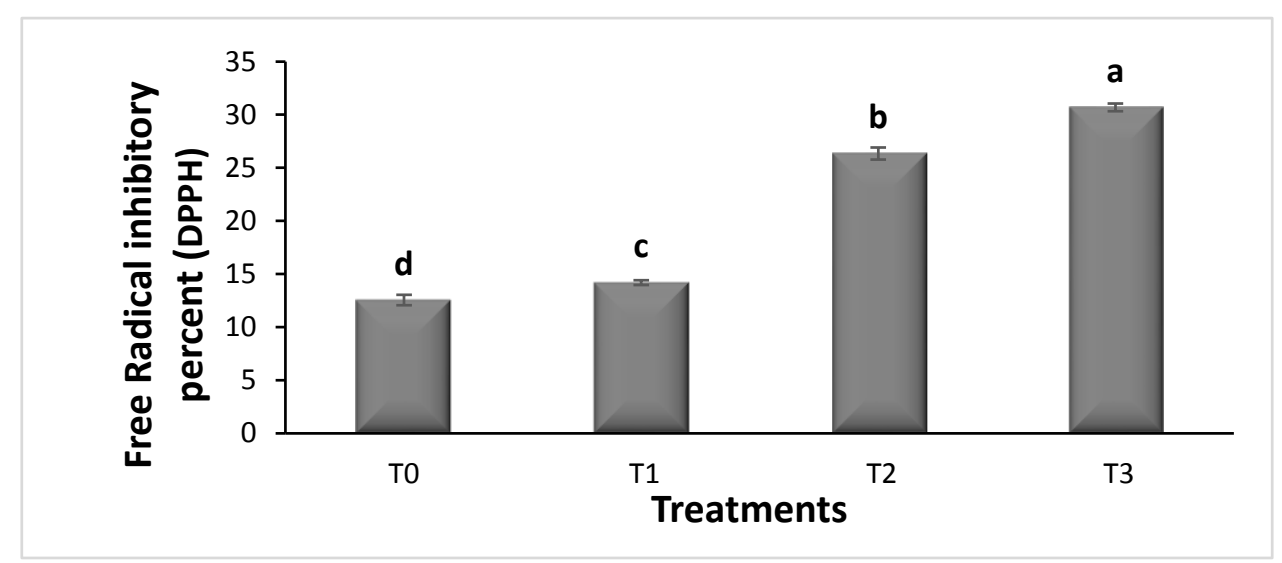

Figure. 1 Comparison of the mean percent of free radical inhibition of shrimp samples with various edible coatings based on L. sativum gum. Coatings with 5\% of Carvacrol (T1), 10\% of Carvacrol (T2), 15\% of Carvacrol (T3). No Carvacrol was used in T0 (Control). Similar letters indicate that there is no significant difference between the values at the probability level of $5 \%$.

\section{Antimicrobial activity of edible coatings}

\section{Antimicrobial activity against bacteria}

(Escherichia coli, Pseudomonas aeruginosa,

Lactobacillus plantarum, Staphylococcus aureus, Salmonella typhimurium)

The results of statistical analysis showed that the treatment had a significant effect on the antimicrobial activity of edible coatings based on L. sativum gum in the control of microorganisms $(p<0.05)$. The average values of the diameter of inhibition zone in the control sample and the coatings containing different levels of carvacrol against the microorganisms examined are compared in Table 2.

Table 2. Comparison of the average diameter of inhibition zone of shrimp samples with various edible coatings based on $L$. sativum gum

\begin{tabular}{llllll}
\hline Treatments & $\begin{array}{l}\text { Salmonella } \\
\text { typhimurium }(\mathbf{m m})\end{array}$ & $\begin{array}{l}\text { Staphylococcus } \\
\text { aureus }(\mathbf{m m})\end{array}$ & $\begin{array}{l}\text { Lactobacillus } \\
\text { plantarum }(\mathbf{m m})\end{array}$ & $\begin{array}{l}\text { Escherichia } \\
\text { coli }(\mathbf{m m})\end{array}$ & $\begin{array}{l}\text { Pseudomonas } \\
\text { aeruginosa }(\mathbf{m m})\end{array}$ \\
\hline T0 & $0.00 \pm 0.00^{\mathrm{d}}$ & $0.00 \pm 0.00^{\mathrm{d}}$ & $0.00 \pm 0.00^{\mathrm{d}}$ & $0.00 \pm 0.00^{\mathrm{d}}$ & $0.00 \pm 0.00^{\mathrm{d}}$ \\
T1 & $0.82 \pm 0.04^{\mathrm{c}}$ & $9.60 \pm 0.05^{\mathrm{c}}$ & $0.15 \pm 0.06^{\mathrm{c}}$ & $0.25 \pm 0.05^{\mathrm{c}}$ & $0.22 \pm 0.04^{\mathrm{c}}$ \\
T2 & $3.06 \pm 0.08^{\mathrm{b}}$ & $18.53 \pm 0.06^{\mathrm{b}}$ & $0.54 \pm 0.04^{\mathrm{b}}$ & $0.86 \pm 0.08^{\mathrm{b}}$ & $0.58 \pm 0.03^{\mathrm{b}}$ \\
T3 & $6.45 \pm 0.07^{\mathrm{a}}$ & $22.93 \pm 0.04^{\mathrm{a}}$ & $0.71 \pm 0.03^{\mathrm{a}}$ & $0.95 \pm 0.04^{\mathrm{a}}$ & $1.24 \pm 0.06^{\mathrm{a}}$ \\
\hline
\end{tabular}

Coatings with 5\% of Carvacrol (T1), 10\% of Carvacrol (T2), 15\% of Carvacrol (T3). No Carvacrol was used in T0 (Control).
In each column, similar letters indicate that there is no significant difference between the values at the probability level of $5 \%$.

\section{Results of the experiments for shrimp samples}

\section{Total bacterial count}

The results of statistical analysis showed that the treatments and storage time had a statistically significant effect on bacterial total count in farmed shrimp ( $p<0.05$ ) (Table 3). Comparison of the mean of bacterial total count of shrimp samples with various edible coatings based on $L$. 
sativum gum showed that the control sample and the coated sample without carvacrol had the highest total microbial load. By increasing the level of carvacrol in the coating solution, the microbial load of all samples decreased significantly $(p<0.05)$. So that the lowest total bacterial count was related to the coated sample with $15 \%$ carvacrol $\left(6.85 \pm 0.09 \log\right.$ cfu g $\left.^{-1}\right)$.

Table 3. Comparison of the mean of bacterial total count $\left(\log \mathrm{CFU} \mathrm{g} \mathrm{g}^{-1}\right)$ of shrimp samples with various edible coatings based on L. sativum gum within 18 days

\begin{tabular}{|c|c|c|c|c|}
\hline Treatments & 1 & 6 & 12 & 18 \\
\hline T0 & $4.48 \pm 0.13^{\mathrm{D}, \mathrm{a}}$ & $0.25 \pm 6.16^{\mathrm{C}, \mathrm{a}}$ & $0.18 \pm 7.79^{\mathrm{B}, \mathrm{a}}$ & $0.11 \pm 9.04^{\mathrm{A}, \mathrm{a}}$ \\
\hline T1 & $4.22 \pm 0.19^{\mathrm{D}, \mathrm{b}}$ & $0.22 \pm 5.77^{\mathrm{C}, \mathrm{b}}$ & $0.13 \pm 7.79^{\mathrm{B}, \mathrm{a}}$ & $0.06 \pm 9.00^{\mathrm{A}, \mathrm{a}}$ \\
\hline $\mathbf{T} 2$ & $3.86 \pm 0.06^{\mathrm{D}, \mathrm{c}}$ & $0.05 \pm 4.88^{\mathrm{C}, \mathrm{c}}$ & $0.16 \pm 6.43^{\mathrm{B}, \mathrm{b}}$ & $0.08 \pm 7.85^{\mathrm{A}, \mathrm{b}}$ \\
\hline $\mathbf{T 3}$ & $3.03 \pm 0.05^{\mathrm{D}, \mathrm{d}}$ & $0.04 \pm 4.29^{\mathrm{C}, \mathrm{d}}$ & $0.22 \pm 5.30^{\mathrm{B}, \mathrm{c}}$ & $0.04 \pm 6.93^{\mathrm{A}, \mathrm{c}}$ \\
\hline $\mathbf{T 4}$ & $2.51 \pm 0.02^{\mathrm{D}, \mathrm{e}}$ & $0 / 07 \pm 3.99^{\mathrm{C}, \mathrm{e}}$ & $0.18 \pm 4.80^{\mathrm{B}, \mathrm{d}}$ & $0.09 \pm 6.85^{\mathrm{A}, \mathrm{c}}$ \\
\hline
\end{tabular}

Coatings with no Carvacrol but edible coating (T1), $5 \%$ of Carvacrol (T2), $10 \%$ of Carvacrol (T3), $15 \%$ of Carvacrol (T4). No Carvacrol or edible coating was used in T0 (Control). In each row or column, respectively similar capital and lowercase letters indicate that there is no significant difference between the values at the probability level of $5 \%$.

\section{Psychrophilic bacterial count}

The results of statistical analysis showed that the treatments and storage time had a statistically significant effect on psychrophilic bacterial count in farmed shrimp $(p<0.05)$. As shown in Table 4 , in the 1st and 18th days of experiments, the highest and lowest number of Psychrophilic bacterial were observed in the control sample and the coated sample with $15 \%$ carvacrol, respectively.

Table 4. Comparison of the mean value of psychrophilic bacterial count $\left(\log \mathrm{CFU} \mathrm{g}{ }^{-1}\right)$ of shrimp samples with various edible coatings based on L. sativum gum within 18 days

\begin{tabular}{lllll}
\hline Treatments & $\mathbf{1}$ & $\mathbf{6}$ & $\mathbf{1 2}$ & $\mathbf{1 8}$ \\
\hline T0 & $5.06 \pm 0.20^{\mathrm{D}, \mathrm{a}}$ & $5.98 \pm 0.10^{\mathrm{C}, \mathrm{a}}$ & $7.95 \pm 0.10^{\mathrm{B}, \mathrm{a}}$ & $8.81 \pm 0.13^{\mathrm{A}, \mathrm{a}}$ \\
T1 & $4.66 \pm 0.08^{\mathrm{D}, \mathrm{b}}$ & $5.91 \pm 0.06^{\mathrm{C}, \mathrm{a}}$ & $7.23 \pm 0.30^{\mathrm{B}, \mathrm{b}}$ & $7.96 \pm 0.13^{\mathrm{A}, \mathrm{b}}$ \\
T2 & $3.89 \pm 0.06^{\mathrm{D}, \mathrm{c}}$ & $4.82 \pm 0.04^{\mathrm{C}, \mathrm{b}}$ & $6.28 \pm 0.13^{\mathrm{B}, \mathrm{c}}$ & $7.22 \pm 0.08^{\mathrm{A}, \mathrm{c}}$ \\
T3 & $3.08 \pm 0.05^{\mathrm{D}, \mathrm{d}}$ & $4.50 \pm 0.25^{\mathrm{C}, \mathrm{c}}$ & $6.03 \pm 0.11^{\mathrm{B}, \mathrm{d}}$ & $6.95 \pm 0.02^{\mathrm{A}, \mathrm{d}}$ \\
T4 & $2.56 \pm 0.02^{\mathrm{D}, \mathrm{e}}$ & $3.83 \pm 0.28^{\mathrm{C}, \mathrm{d}}$ & $5.24 \pm 0.13^{\mathrm{B}, \mathrm{e}}$ & $6.66 \pm 0.07^{\mathrm{A}, \mathrm{e}}$ \\
\hline
\end{tabular}

Coatings with no Carvacrol but edible coating (T1), $5 \%$ of Carvacrol (T2), $10 \%$ of Carvacrol (T3), 15\% of Carvacrol (T4). No Carvacrol or edible coating was used in T0 (Control). In each row or column, respectively similar capital and lowercase letters indicate that there is no significant difference between the values at the probability level of $5 \%$.

\section{pH Measurement}

The results of statistical analysis of the data showed that the treatments and storage time had a significant effect on the $\mathrm{pH}$ of farmed shrimp $(p<0.05)$. As shown in Table 5, on the first day, the lowest $\mathrm{pH}$ was observed for the sample containing 5\% carvacrol and there was no statistically significant difference between the $\mathrm{pH}$ values of other samples ( $p>0.05)$. During the storage period of 18 days, the $\mathrm{pH}$ of all samples was significantly increased $(p<0.05)$, but its rate of increase in control sample and coating without carvacrol was significantly higher than other samples. So that on the last day of storage, control sample and the sample coated with a solution free of carvacrol had the highest $\mathrm{pH}$ and the lowest $\mathrm{pH}$ was observed for the coated sample with 15\% Carvacrol. 
Table 5. Comparison of the mean of $\mathrm{pH}$ of shrimp samples with various edible coatings based on L. sativum gum within 18 days

\begin{tabular}{lllll}
\hline Treatments & $\mathbf{1}$ & $\mathbf{6}$ & $\mathbf{1 2}$ & $\mathbf{1 8}$ \\
\hline T0 & $7.14 \pm 0.01^{\mathrm{D}, \mathrm{a}}$ & $7.60 \pm 0.02^{\mathrm{C}, \mathrm{a}}$ & $7.67 \pm 0.01^{\mathrm{B}, \mathrm{a}}$ & $7.92 \pm 0.05^{\text {A.a }}$ \\
T1 & $7.15 \pm 0.01^{\mathrm{D}, \mathrm{a}}$ & $7.58 \pm 0.01^{\mathrm{C}, \mathrm{a}}$ & $7.60 \pm 0.00^{\mathrm{B}, \mathrm{b}}$ & $7.90 \pm 0.04^{\text {A.a }}$ \\
T2 & $7.08 \pm 0.02^{\mathrm{D}, \mathrm{b}}$ & $7.44 \pm 0.03^{\mathrm{C}, \mathrm{b}}$ & $7.50 \pm 0.01^{\mathrm{B}, \mathrm{c}}$ & $7.64 \pm 0.03^{\mathrm{A}, \mathrm{b}}$ \\
T3 & $7.11 \pm 0.04^{\mathrm{D}, \mathrm{a}, \mathrm{b}}$ & $7.45 \pm 0.02^{\mathrm{C}, \mathrm{b}}$ & $7.50 \pm 0.02^{\mathrm{B}, \mathrm{c}}$ & $7.61 \pm 0.02^{\mathrm{A}, \mathrm{b}}$ \\
T4 & $7.15 \pm 0.02^{\mathrm{D}, \mathrm{a}}$ & $7.41 \pm 0.01^{\mathrm{C}, \mathrm{b}}$ & $7.46 \pm 0.03^{\mathrm{B}, \mathrm{d}}$ & $7.55 \pm 0.03^{\mathrm{A}, \mathrm{c}}$ \\
\hline
\end{tabular}

Coatings with no Carvacrol but edible coating (T1), $5 \%$ of Carvacrol (T2),10\% of Carvacrol (T3), 15\% of Carvacrol (T4). No Carvacrol or edible coating was used in T0 (Control). In each row or column, respectively similar capital and lowercase letters indicate that there is no significant difference between the values at the probability level of $5 \%$.

\section{Thiobarbituric Acid Index (TBA)}

The results of statistical analysis of the data showed that the treatments and storage time had a statistically significant effect on the TBA index of breeding shrimp $(p<0.05)$. As shown in Table 6, in the 1st and 18th days of experiments, the highest and lowest number of levels of TBA were related to the control sample and the coated sample with $15 \%$ carvacrol, respectively.

Table 6. Comparison of the mean value of TBA ( $\mathrm{mg} \mathrm{MDA} \mathrm{kg}{ }^{-1}$ ) of shrimp samples with various edible coatings based on L. sativum gum within 18 days

\begin{tabular}{lllll}
\hline Treatments & $\mathbf{1}$ & $\mathbf{6}$ & $\mathbf{1 2}$ & $\mathbf{1 8}$ \\
\hline T0 & $0.20 \pm 0.00^{\mathrm{D}, \mathrm{a}}$ & $0.49 \pm 0.02^{\mathrm{C}, \mathrm{a}}$ & $0.74 \pm 0.06^{\mathrm{B}, \mathrm{a}}$ & $0.91 \pm 0.05^{\mathrm{A} . \mathrm{a}}$ \\
T1 & $0.10 \pm 0.01^{\mathrm{D}, \mathrm{b}}$ & $0.42 \pm 0.02^{\mathrm{C}, \mathrm{b}}$ & $0.64 \pm 0.05^{\mathrm{B}, \mathrm{b}}$ & $0.84 \pm 0.04^{\mathrm{A} . \mathrm{b}}$ \\
T2 & $0.08 \pm 0.01^{\mathrm{D}, \mathrm{b}}$ & $0.41 \pm 0.03^{\mathrm{C}, \mathrm{b}}$ & $0.60 \pm 0.12^{\mathrm{B}, \mathrm{b}}$ & $0.75 \pm 0.02^{\mathrm{A}, \mathrm{c}}$ \\
T3 & $0.08 \pm 0.00^{\mathrm{D}, \mathrm{b}}$ & $0.31 \pm 0.07^{\mathrm{C}, \mathrm{c}}$ & $0.46 \pm 0.06^{\mathrm{B}, \mathrm{c}}$ & $0.65 \pm 0.05^{\mathrm{A}, \mathrm{d}}$ \\
T4 & $0.05 \pm 0.02^{\mathrm{D}, \mathrm{c}}$ & $0.29 \pm 0.02^{\mathrm{C}, \mathrm{c}}$ & $0.37 \pm 0.06^{\mathrm{B}, \mathrm{d}}$ & $0.50 \pm 0.01^{\mathrm{A}, \mathrm{e}}$ \\
\hline
\end{tabular}

Coatings with no Carvacrol but edible coating (T1), $5 \%$ of Carvacrol (T2), $10 \%$ of Carvacrol (T3), $15 \%$ of Carvacrol (T4). No Carvacrol or edible coating was used in $\mathrm{T} 0$ (Control). In each row or column, respectively similar capital and lowercase letters indicate that there is no significant difference between the values at the probability level of $5 \%$.

\section{Texture analysis}

The results of statistical analysis of the data showed that the treatments did not have a significant effect on the hardness of the shrimp tissue $(p>0.05)$, but the effect of storage time was significant $(p<0.05)$. As shown in table 7 , on the first day, there was no significant difference between the hardness values of different shrimp samples $(p>0.05)$. During the storage period, the hardness of the control sample, the sample coatings with no carvacrol but edible coating and 5\% carvacrol coating were initially increased significantly (up to 6 days) and then decreased to the last day of storage $(p<0.05)$, While in the coatings with $10 \%$ and $15 \%$ carvacrol, the hardness of the tissue gradually increased during storage. On the last day of storage, the coatings with no carvacrol but edible coating sample had the least hardness.

Table 7. Comparison of the mean value of tissue hardness $(\mathrm{N})$ in shrimp samples with various edible coatings based on $L$. sativum gum within 18 days

\begin{tabular}{lllll}
\hline Treatments & $\mathbf{1}$ & $\mathbf{6}$ & $\mathbf{1 2}$ & $\mathbf{1 8}$ \\
\hline T0 & $7.01 \pm 0.37^{\mathrm{D}, \mathrm{a}}$ & $15.2 \pm 1.24^{\mathrm{A}, \mathrm{ab}}$ & $13.65 \pm 0.45^{\mathrm{B}, \mathrm{bc}}$ & $12.20 \pm 0.30^{\mathrm{C}, \mathrm{b}}$ \\
T1 & $6.21 \pm 1.82^{\mathrm{D}, \mathrm{a}}$ & $17.03 \pm 0.66^{\mathrm{A}, \mathrm{a}}$ & $14.45 \pm 0.2^{\mathrm{B}, \mathrm{ab}}$ & $8.22^{\mathrm{a}} \pm .16^{\mathrm{C}, \mathrm{c}}$ \\
T2 & $7.48 \pm 1.68^{\mathrm{C}, \mathrm{a}}$ & $16.01 \pm 1.87^{\mathrm{A}, \mathrm{a}}$ & $12.63 \pm 0.98^{\mathrm{B}, \mathrm{c}}$ & $12.55^{\mathrm{a}} \pm 2.26^{\mathrm{B}, \mathrm{b}}$ \\
T3 & $7.65^{\mathrm{B}} \pm 1.03^{\mathrm{C}, \mathrm{a}}$ & $13.88 \pm 2.7^{\mathrm{B}, \mathrm{b}}$ & $14.88 \pm 0.33^{\mathrm{B}, \mathrm{a}}$ & $16.74^{\mathrm{A}} \pm .52^{\mathrm{A}, \mathrm{a}}$ \\
T4 & $6.34 \pm 1.76^{\mathrm{B}, \mathrm{a}}$ & $15.92 \pm 1.29^{\mathrm{A}, \mathrm{ab}}$ & $15.29 \pm 0.41^{\mathrm{A}, \mathrm{a}}$ & $15.45 \pm 0.77^{\mathrm{A}, \mathrm{a}}$ \\
\hline
\end{tabular}

Coatings with no Carvacrol but edible coating (T1), $5 \%$ of Carvacrol (T2), $10 \%$ of Carvacrol (T3), 15\% of Carvacrol (T4). No Carvacrol or edible coating was used in T0 (Control). In each row or column, respectively similar capital and lowercase letters indicate that there is no significant difference between the values at the probability level of $5 \%$. 


\section{Color indexes of shrimp samples}

The results of statistical analysis of the data showed that the treatments and storage time had a significant effect on $\mathrm{L}^{*}, \mathrm{a}^{*}$ and $\mathrm{b}^{*}$ values of farmed shrimp $(p<0.05)$. Mean values of
Intensity of color indexes (lightness (L), rednessgreenness (a), yellowness-blueness (b)) of shrimp samples with various edible coatings based on $L$. sativum gum within the experiment are shown in Table 8.

Table 8. Comparison of the mean value of Intensity of color indexes $\left(L^{*}, a^{*}, b^{*}\right)$ of shrimp samples with various edible coatings based on $L$. sativum gum within the experiment

\begin{tabular}{|c|c|c|c|c|c|}
\hline Color indexes & Treatments & 1 & 6 & 12 & 18 \\
\hline \multirow{5}{*}{$\mathbf{L}^{*}$} & T0 & $67.29 \pm 1.65^{\mathrm{A}, \mathrm{d}}$ & $65.51 \pm 0.75^{\mathrm{B}, \mathrm{b}}$ & $61.92 \pm 0.38^{\mathrm{C}, \mathrm{c}}$ & $59.91 \pm 1.07^{\text {D.c }}$ \\
\hline & $\mathrm{T} 1$ & $69.00 \pm 0.16^{\mathrm{A}, \mathrm{c}}$ & $65.92 \pm 1.14^{\mathrm{B}, \mathrm{b}}$ & $63.00 \pm 0.38^{\mathrm{C}, \mathrm{b}}$ & $60.36 \pm 0.34^{\text {D.bc }}$ \\
\hline & $\mathrm{T} 2$ & $69.81 \pm 0.51^{\mathrm{A}, \mathrm{ab}}$ & $67.05 \pm 0.16^{\mathrm{B}, \mathrm{a}}$ & $65.24 \pm 0.12^{\mathrm{C}, \mathrm{a}}$ & $60.75 \pm 0.98^{\mathrm{D}, \mathrm{b}}$ \\
\hline & $\mathrm{T} 3$ & $69.71 \pm 0.57^{\mathrm{A}, \mathrm{b}}$ & $67.39 \pm 0.27^{\text {В,a }}$ & $65.71 \pm 0.42^{\mathrm{C}, \mathrm{a}}$ & $61.99 \pm 0.26^{\mathrm{D}, \mathrm{a}}$ \\
\hline & $\mathrm{T} 4$ & $70.28 \pm 0.16^{\mathrm{A}, \mathrm{a}}$ & $67.54 \pm 0.84^{\mathrm{B}, \mathrm{a}}$ & $65.35 \pm 0.49^{\mathrm{C}, \mathrm{a}}$ & $62.41 \pm 0.52^{\mathrm{D}, \mathrm{a}}$ \\
\hline \multirow{5}{*}{$\mathbf{a}^{*}$} & T0 & $-1.68 \pm 0.69^{\mathrm{A}, \mathrm{a}}$ & $-2.81 \pm 0.91^{\mathrm{B}, \mathrm{b}}$ & $-1.28 \pm 0.24^{\mathrm{A}, \mathrm{c}}$ & $-1.08 \pm 0.88^{\text {A.b }}$ \\
\hline & $\mathrm{T} 1$ & $-2.18 \pm 0.09^{\mathrm{B}, \mathrm{c}}$ & $-2.37 \pm 0.47^{\text {В,ab }}$ & $-0.98 \pm 0.20^{\mathrm{A}, \mathrm{bc}}$ & $-0.61 \pm 0.22^{\text {A.b }}$ \\
\hline & $\mathrm{T} 2$ & $-1.87 \pm 0.32^{\mathrm{B}, \mathrm{ab}}$ & $-2.18 \pm 0.58^{\mathrm{B}, \mathrm{a}}$ & $-0.74 \pm 0.19^{\mathrm{A}, \mathrm{b}}$ & $-0.43 \pm 0.55^{\mathrm{A}, \mathrm{a}}$ \\
\hline & T3 & $-1.96 \pm 0.09^{\mathrm{B}, \mathrm{b}}$ & $-1.83 \pm 0.61^{\mathrm{B}, \mathrm{a}}$ & $-0.47 \pm 0.05^{\mathrm{A}, \mathrm{a}}$ & $-0.16 \pm 0.17^{\mathrm{A}, \mathrm{a}}$ \\
\hline & $\mathrm{T} 4$ & $-1.65 \pm 0.20^{\mathrm{B}, \mathrm{a}}$ & $-2.25 \pm 0.37^{\mathrm{C}, \mathrm{ab}}$ & $-0.35 \pm 0.07^{\mathrm{A}, \mathrm{a}}$ & $-0.11 \pm 0.03^{\mathrm{A}, \mathrm{a}}$ \\
\hline \multirow{5}{*}{$\mathbf{b}^{*}$} & T0 & $0.78 \pm 0.23^{\mathrm{D}, \mathrm{a}}$ & $2.53 \pm 0.83^{\mathrm{C}, \mathrm{a}}$ & $7.86 \pm 1.01^{\mathrm{B}, \mathrm{a}}$ & $16.48 \pm 0.75^{\text {A.a }}$ \\
\hline & $\mathrm{T} 1$ & $1.01 \pm 0.19^{\mathrm{D}, \mathrm{a}}$ & $1.34 \pm 0.50^{\mathrm{C}, \mathrm{a}}$ & $6.90 \pm 0.34^{\mathrm{B}, \mathrm{a}}$ & $12.76 \pm 0.49^{\text {A.a }}$ \\
\hline & $\mathrm{T} 2$ & $0.76 \pm 0.31^{\mathrm{D}, \mathrm{b}}$ & $1.45 \pm 0.42^{\mathrm{C}, \mathrm{b}}$ & $5.41 \pm 0.37^{\mathrm{B}, \mathrm{c}}$ & $10.54 \pm 0.60^{\mathrm{A}, \mathrm{b}}$ \\
\hline & T3 & $0.67 \pm 0.23^{\mathrm{D}, \mathrm{ab}}$ & $1.03 \pm 0.22^{\mathrm{C}, \mathrm{b}}$ & $4.45 \pm 0.60^{\mathrm{B}, \mathrm{c}}$ & $8.95 \pm 1.31^{\mathrm{A}, \mathrm{b}}$ \\
\hline & $\mathrm{T} 4$ & $0.86 \pm 0.20^{\mathrm{D}, \mathrm{a}}$ & $0.86 \pm 0.18^{\mathrm{C}, \mathrm{b}}$ & $4.27 \pm 0.24^{\mathrm{B}, \mathrm{d}}$ & $9.79 \pm 0.95^{\mathrm{A}, \mathrm{c}}$ \\
\hline
\end{tabular}

Coatings with no Carvacrol but edible coating (T1), $5 \%$ of Carvacrol (T2), $10 \%$ of Carvacrol (T3), $15 \%$ of Carvacrol (T4). No Carvacrol or edible coating was used in T0 (Control). In each row or column, respectively similar capital and lowercase letters indicate that there is no significant difference between the values at the probability level of $5 \%$.

\section{Sensory analysis}

The results of statistical analysis of the data showed that the treatments and storage time had a statistically significant effect on the overall acceptability scores of farmed shrimp $(p<0.05)$.
The average changes in the overall acceptability rates of of shrimp samples with various edible coatings based on $L$. sativum gum within the experiment were shown in Table 9.

Table 9. Comparison of the mean value of overall acceptability of shrimp samples with various edible coatings based on L. sativum gum within the experiment

\begin{tabular}{lllll}
\hline Treatments & $\mathbf{1}$ & $\mathbf{6}$ & $\mathbf{1 2}$ & $\mathbf{1 8}$ \\
\hline T0 & $8.00 \pm 0.00^{\mathrm{A}, \mathrm{ab}}$ & $7.40 \pm 0.55^{\mathrm{B}, \mathrm{b}}$ & $4.40 \pm 0.55^{\mathrm{C}, \mathrm{e}}$ & $4.20 \pm 0.45^{\mathrm{C}, \mathrm{d}}$ \\
T1 & $8.00 \pm 0.00^{\mathrm{A}, \mathrm{ab}}$ & $8.00 \pm 0.00^{\mathrm{A}, \mathrm{a}}$ & $5.00 \pm 0.71^{\mathrm{B}, \mathrm{d}}$ & $4.80^{\mathrm{a}} \pm 0.84^{\mathrm{B}, \mathrm{c}}$ \\
T2 & $8.20 \pm 0.45^{\mathrm{A}, \mathrm{a}}$ & $7.80 \pm 0.45^{\mathrm{B}, \mathrm{a}}$ & $5.40 \pm 0.55^{\mathrm{C}, \mathrm{c}}$ & $5.60_{0.55^{\mathrm{C}, \mathrm{b}}}^{\mathrm{A}}$ \\
T3 & $7.80 \pm 0.45^{\mathrm{A}, \mathrm{b}}$ & $7.80 \pm 0.45^{\mathrm{A}, \mathrm{a}}$ & $5.80 \pm 0.45^{\mathrm{C}, \mathrm{b}}$ & $6.40 \pm 0.55^{\mathrm{B}, \mathrm{a}}$ \\
T4 & $8.00 \pm 0.00^{\mathrm{A}, \mathrm{ab}}$ & $7.80 \pm 0.45^{\mathrm{A}, \mathrm{a}}$ & $6.60 \pm 0.55^{\mathrm{B}, \mathrm{a}}$ & $6.60 \pm 0.55^{\mathrm{B}, \mathrm{a}}$ \\
\hline
\end{tabular}

Coatings with no Carvacrol but edible coating (T1), 5\% of Carvacrol (T2),10\% of Carvacrol (T3), 15\% of Carvacrol (T4). No Carvacrol or edible coating was used in T0 (Control). In each row or column, respectively similar capital and lowercase letters indicate that there is no significant difference between the values at the probability level of $5 \%$.

\section{Melanosis phenomenon of shrimp samples}


The results of statistical analysis of the data showed that the treatments and storage time had a significant effect on melanosis in farmed shrimp $(p<0.05)$. The average changes of the
Melanosis phenomenon of of shrimp samples with various edible coatings based on $L$. sativum gum within the experiment were shown in Table 10.

Table 10. Comparison of the mean value of Melanosis phenomenon of shrimp samples with various edible coatings based on L. sativum gum within the experiment

\begin{tabular}{lllll}
\hline Treatments & $\mathbf{1}$ & $\mathbf{6}$ & $\mathbf{1 2}$ & $\mathbf{1 8}$ \\
\hline T0 & $1.00 \pm 0.00^{\mathrm{C}, \mathrm{a}}$ & $1.80 \pm 0.55^{\mathrm{B}, \mathrm{a}}$ & $3.60 \pm 0.55^{\mathrm{A}, \mathrm{a}}$ & $3.80 \pm 0.55^{\mathrm{A}, \mathrm{a}}$ \\
T1 & $1.00 \pm 0.00^{\mathrm{C}, \mathrm{a}}$ & $1.40 \pm 0.55^{\mathrm{B}, \mathrm{b}}$ & $3.20 \pm 0.45^{\mathrm{A}, \mathrm{b}}$ & $3.40 \pm 0.55^{\mathrm{A}, \mathrm{b}}$ \\
T2 & $1.00 \pm 0.00^{\mathrm{D}, \mathrm{a}}$ & $1.40 \pm 0.55^{\mathrm{C}, \mathrm{b}}$ & $3.00 \pm 0.00^{\mathrm{B}, \mathrm{b}}$ & $3.20 \pm 0.55^{\mathrm{A}, \mathrm{b}}$ \\
T3 & $1.00 \pm 0.00^{\mathrm{C}, \mathrm{a}}$ & $1.00 \pm 0.00^{\mathrm{C}, \mathrm{c}}$ & $1.80 \pm 0.45^{\mathrm{B}, \mathrm{c}}$ & $2.20 \pm 0.45^{\mathrm{A}, \mathrm{c}}$ \\
T4 & $1.00 \pm 0.00^{\mathrm{B}, \mathrm{a}}$ & $1.00 \pm 0.00^{\mathrm{B}, \mathrm{c}}$ & $1.60 \pm 0.55^{\mathrm{A}, \mathrm{c}}$ & $1.80 \pm 0.45^{\mathrm{A}, \mathrm{d}}$ \\
\hline
\end{tabular}

Coatings with no Carvacrol but edible coating (T1), $5 \%$ of Carvacrol (T2), $10 \%$ of Carvacrol (T3), $15 \%$ of Carvacrol (T4). No Carvacrol or edible coating was used in T0 (Control). In each row or column, respectively similar capital and lowercase letters indicate that there is no significant difference between the values at the probability level of 5\%.

\section{Discussion}

Color indexes of films and coatings used in food packaging are of considerable essence as they play a major role in the consumer's acceptance. The results of the present study showed that the addition of different amounts of carvacrol did not have a statistically significant effect on the amount of redness $\left(a^{*}\right)$ in the edible coating based on Lepidium sativum seed gum $(p>0.05)$. However, the color brightness $\left(\mathrm{L}^{*}\right)$ and the amount of yellowness $\left(\mathrm{b}^{*}\right)$ in the coating were under the influence of carvacrol in a manner that the control sample showed the lowest $\mathrm{L}^{*}$ and the highest $\mathrm{b}^{*}$ values, and the addition of carvacrol to the film samples increased the color brightness and decreased the $b^{*}$ index. Karami Moghaddam, Emam jomeh and Yasini Ardakani (2016) showed that increasing the concentration of the pomegranate peel extract in sodium caseinate films increased the redness and decreased the brightness in the film samples; they also found that the addition of this extract with lower concentrations did not have a significant effect on the color brightness. Similar results were obtained from Mehdizadeh, Tajik, Razavi Rohani and Oromiehie (2012). They reported that the addition of thyme essential oil to chitosan films significantly influenced the color measurement indexes.

Study of inhibitory activity of the DPPH radical by the coated samples showed that adding carvacrol to the coating made from cress seed gum significantly increased antioxidant activity of the edible coating $(p<0.05)$. This antioxidant activity was enhanced when larger amounts of carvacrol were added to the samples. Barzegaran, Jokar and Javanmard Dakheli (2014) produced polyamide films containing green tea extracts and investigated their antioxidant properties. They noticed that the antioxidant property of the films increased from 0 to $88.750 \%$ when the green tea extract content increased from zero to $20 \%$. In this research, results indicated that the antimicrobial activity of the coating made from garden cress seed gum lacked antimicrobial activity against 
the tested bacteria. However, adding carvacrol to this coating caused it to exhibit antimicrobial activity. The antibacterial effect of carvacrol was noticed by the creation of inhibition zones. Addition of carvacrol to the garden cress seed gum increased its diffusion into the culture medium and caused formation of inhibition zones. Ariaei, Tavakolipour, Rezaei and Elhamirad (2013) demonstrated that methyl cellulose-based edible films lacked any antimicrobial activity against various Grampositive and Gram-negative microorganisms. However, adding and using larger amounts of zolang (Froripia subpinnata) extract to this film increased its antimicrobial activity.

Microbial growth is one of the main causes of food decay (Chytiri, Chouliara, Savvaidis \& Kontominas 2004). Results indicated that adding carvacrol to the coating solution decreased microbial growth and increased shrimp shelf life. Tarkhasi, Zakipour Rahimabadi, Alizadeh doughikollaee and Yousef Elahi (2016) also noticed that the total bacterial count in the various samples of silver carp fillets increased significantly during the storage time. However, the rate of increase was lower in samples containing pomegranate skin extract compared to the control sample. Chaparro-Hernandez, Ruiz-Cruz, MarquezRios, Ocano-Higuera, Valenzuela-Lopez, V., Ornelas-Paz and Del-Toro-Sanchez (2015) showed that coating tilapia fillets with edible chitosan containing carvacrol reduced total microbial load. The main group of microorganisms responsible for decay of fresh aquatic organisms is the psychrophilic bacteria (Sallam, 2007). Like total bacterial count, the number of psychrophilic bacteria in all samples studied in the present research significantly increased with the passage of time $(p<0.05)$, but the rates of their increase were higher in the control sample and in samples coated with a solution lacking carvacrol compared to the other samples. The $\mathrm{pH}$ values of all the studied samples increased significantly, but in samples containing high levels of carvacrol this increase was considerably smaller than in the control sample and in the sample with a coating that lacked carvacrol. The $\mathrm{pH}$ increase in shrimp samples during the storage period is due to production of volatile bases (like ammonia) and of total volatile nitrogen (Simeonidou, Govaris \& Vareltzis 1998). Lu, Ding, Ye, and Liu (2010) also observed that use of cinnamon essential oil in calcium coating preserved quality of fresh fish and controlled $\mathrm{pH}$ changes in them. Results of the present study on the value of the TBA index in shrimp samples demonstrated that use of the coating prepared from garden cress seed gum containing various carvacrol levels reduced the rate of oxidation reaction. The rate of this destructive reaction declined with increases in carvacrol levels of the coating solution and the value of the TBA index also decreased. This result is in agreement with those obtained by Aletayeb, Roomiani and Ghaeni (2016) who reported that use of sodium alginate and cinnamon essential oil reduced the value of the TBA index in silver carp fillets.

Softening of tissue is one of the factors that must be prevented during the storage period because it influences organoleptic acceptance of the product by consumers. Results of the 
present research indicated that use of coating solution containing various levels of carvacrol did not significantly affect hardness of shrimp tissues on the first day of storage $(p>0.05)$. Nevertheless, tissue hardness in the samples containing various carvacrol levels was considerably higher on the last day of storage compared to the control sample and the sample coated with a coating solution that lacked carvacrol. Conversely, Mohan, Ravishankar, Lalitham and Gopal (2012) reported that final hardness of sardine fillets treated with 1 and 2 percent chitosan coating was less than their initial harness. Results of the study on color indicators of shrimp samples showed that the samples coated with garden cress seed gum coating containing various levels of carvacrol were lighter colored and redder than the control sample during the storage period. This indicated that the coated samples color preservation better compared to the control sample. Similar to these results, Pasbani and Amiri (2017) studied effects of the edible coating of Aloe vera extract together with the essential oil of zolang (Froriepia subpinnata) on qualitative parameters of fresh beef. They noticed that use of the coating containing Aloe vera and this essential oil considerably increased the light color of the meat samples. Results of the present research also demonstrated the desirable effect of cress seed gum coating containing high levels of carvacrol on sensory characteristics of shrimp. Increased levels of carvacrol preserved the sensory scores better by decreasing the rate of lipid oxidation reaction and through reducing the total microbial load and the number of psychrophilic bacteria. Similar to this results, Vasilatos and Savvaidis (2013) studied effects of chitosan and of rosemary essential oil on increasing shelf life of turkey meat in refrigerator. They reported that sensory characteristics of the treated samples including flavor and smell improved. Oxidation darkens the membrane under the skin and dark spots appear on body surfaces of shrimps (Moeini \& Pazira 2001). Results of the study about effects that the edible coating based on garden cress seed gum containing various levels of carvacrol had on the phenomenon of melanosis coli indicated that there were no statistically significant differences between the intensity of melanosis in the various shrimp samples at the beginning of the storage period $(p>0.05)$. During the storage period, the melanosis phenomenon gradually increased in most studied samples. On the last day of the storage period, the control sample followed by the sample coated with a solution lacking carvacrol exhibited the highest intensity of melanosis and the samples with coating containing 10 and 15 percent carvacrol had the lowest intensity of melanosis. This result is consistence with study of Nasiri, MoosaviNasab, Shekarforoush and Golmakani (2014) who reported that Zataria multiflora (Shirazi thyme) essential oil was able to reduced the trend of melanosis during the storage period of whiteleg shrimp (Litopenaeus vannamei) by inhibiting polyphenol oxidase because it contained polyphenolic compounds like thymol and carvacrol.

\section{Conclusion}

The results of present study clearly indicated that the effect of cress seed gum coating 
containing carvacrol on shrimp samples was to retain their good quality characteristics and extend the shelf life during refrigerated storage, which was supported by the results of microbiological, chemical, and sensorial properties.

\section{Conflict of interests}

The authors declare that there is no conflict of interest.

\section{References}

Ariaei P., Tavakolipour H., Rezaei M. \& Elhamirad A. (2013) Antimicrobial activity of methyl cellulose based edible film enriched with pimpinella affinis oil on the Hypophthalmichthys molitrix fillet under refrigerator storage condition. Electronic Journal of Food Processing and Preservation 5(1), 13-26. [In Persian]

Aletayeb E., Roomiani L. \& Ghaeni M. (2016) Effect of sodium alginate and cinnamon essential oil on shelf life of silver carp (Hypophthalmichthys molitrix) fillets in refrigerated storage. Journal of Food Microbiology 3(2):45-59. [In Persian]

Aminifar M. \& Emam-Djomeh Z. (2014) Changes of texture, microstructure and free fatty acid contents of Lighvan cheese during accelerated ripening with lipase. Journal of Agriculture Science and Technology, 16, 113123.

Bahram S., Rezaei M., Soltani M., Kamali A., Ojagh S.M. \& Abdollahi M. (2012) Whey protein concentrate edible film activated with cinnamon essential oil. Journal of Food Processing and Technology, 38, 1251-1258.

Barzegaran A.A., Jokar M. \& Javanmard Dakheli M. (2014) Effects of Green Tea extract on physicochemical and antioxidant properties of polyamide packaging film. Journal of Chemical Health Risks, 4(3), 41-48.

Chaparro-Hernandez S., Ruiz-Cruz S., Marquez-Rios E., Ocano-Higuera V.M., Valenzuela-Lopez V., Ornelas-Paz J.J. \& DelToro-Sanchez C.L. (2015) Effect of chitosancarvacrol edible coatings on the quality and shelf life of tilapia (Oreochromis niloticus) fillets stored in ice. Food Science and Technology, 35(4), 734-741.

Chytiri S., Chouliara I., Savvaidis I.N. \& Kontominas M.G. (2004) Chemical and sensory assessment of iced whole and filleted aquaculture Rainbow trout. Food Microbiology, 21, 157-165.

Gimenez B., Gomez-Guillen M.C., LopezCaballero M.E., Gomez-Estaca J. \& Montero P. (2012) Role of sepiolite in the release of active compounds from gelatin egg white films. Food Hydrocolloids, 27(2), 475-486.

Ghorbani A., Maghsoudlou Y., Aalami A., Ghorbani M. \& Sadeghi A.R. (2016) Effect of cress seeds mucilage on shelf life of Button Mushroom. The journal of Innovative Food Technologies 3(12), 89-96. [In Persian]

Haddar A., Sellimi S., Ghannouchi R., Alvarez O.M., Nasri M. \& Bougatef A. (2012) Functional, antioxidant and film-forming 
properties of tuna-skin gelatin with a brown algae extract. International Journal of Biological Macromolecules, 51(4), 477-483.

Hyldgaard M., Mygind T. \& Meyer R.L. (2012) Essential oils in food preservation: mode of action, synergies, and interactions with food matrix components. Frontiers in microbiology, 3, p.12.

Institute of Standards and Industrial Research of Iran (ISIRI). (2007) Milk and milk products - determination of titrable acidity and value $\mathrm{pH}$ - test method 2852. Iran: The Institute of Standards \& Industrial Research of Iran. [In Persian]

Jouki M., Khazaei N., Ghasemlou M. \& HadiNezhad M., (2013) Effect of glycerol concentration on edible film production from cress seed carbohydrate gum. Carbohydrate Polymers, 96(1), pp.39-46.

Karami Moghaddam A., Emam jomeh Z. \& Yasini Ardakani S.A. (2016) Effect of pomegranate peel extract on the antibacterial and mechanical properties of sodium caseinate film. Iranian Journal of Biosystem Engineering, 45(2), 89-177. [In Persian]

Khazaei N., Esmaiili M. \& Emam Djomeh Z. (2016) Effect of active edible coatings made by basil seed gum and thymol on oil uptake and oxidation in shrimp during deep-fat frying. Carbohydrate Polymers, 137, 249-254.

Kuorwel K., Carn, M., Sonneveld K., Miltz J. \& Bigger S. (2011) Antimicrobial activity of biodegradable polysaccharide and protein- based films containing active agents. Journal of Food Science, 76, 90-102.

Lu F., Ding Y., Ye X. \& Liu D. (2010) Cinnamon and nisin in alginate calcium coating maintain quality of fresh northern snakehead fish fillets. $L W T$ - Food Science and Technology, 43, 1331-1335.

Mehdizadeh T., Tajik H., Razavi Rohani S.M. \& Oromiehie A.R. (2012) Antibacterial, antioxidant and optical properties of edible starch-chitosan composite film containing Thymus kotschyanus essential oil. Veterinary Research Forum, 3(3), 167-173.

Moeini S. \& Pazira E. (2001) Effect of frozen storage in cultured and sea shrimp quality. Iranian Journal of Natural Research, 57, 469478.

Mohan C.O., Ravishankar C.N., Lalitha K.V. \& Gopal T.K.S. (2012) Effect of chitosan edible coating on the quality of double filleted Indian oil sardine (Sardinella longiceps) during chilled storage. Food Hydrocolloids, 26(1), 167-174.

Mohebi E. \& Shahbazi Y. (2017) Application of chitosan and gelatin based active packaging film for peeled shrimp preservation: A novel functional wrapping design. Journal of Food and Technology, 76, 108-116.

Montero P., Martinez-Alvarez O. \& GomezGuillen M.C. (2004) Effectiveness of onboard application of 4-Hexylresorcinol in inhibiting melanosis in shrimp (Parapenaeus longirostris). Journal of Food Science, 69, C643-C647. 
Moosavi-Nasab S., Moosavi-Nasab M., Mesbahi Gh., Jamalian J. \& Maghsoudlou Y. (2014) Ice glazing of frozen shrimp using chitosan hydrocolloid for improving its qualitative properties. Electronic Journal of Food Processing and Preservation, 5(2), 1-17. [In Persian]

Nasiri, E., Moosavi-Nasab, M., Shekarforoush, S.S. \& Golmakani, M.T. (2014) The effects of Zataria multiflora on inhibition of polyphenoloxidase and melanosis formation in shrimp (Litopenaeus vannamei). Iranian Scientific fisheries Journal, 23(3), 109-119. [In Persian]

Nirmal, N.P. \& Benjakul, S. (2009) Effect of ferulic acid on inhibition of polyphenoloxidase and quality changes of Pacific white shrimp (Litopenaeus vannamei) during iced storage. Food Chemistry, 116, 323-331.

Pasbani E \& Amiri S. (2017) Evaluating the Effect of Aleo Vera Gel Coating and Solid Lipid Nano-particles Containing Thymol Seed (Carum copticum) Essential oil on shelf life of fresh beef. Iranian Journal of Nutrition Sciences \& Food Technology 12(2), 75-86. [In Persian]

Rodrigues J., Carvalho R., Souza N., Oliveira K., Franco O., Schaffner D., Souza E. \& Magnani M. (2017) Effects of oregano essential oil and carvacrol on biofilms of Staphylococcus aureus from food-contact surfaces. Journal of Food Control, 73, 1237-1246.

Sacchetti G., Maietti S., Muzzoli M., Scaglianti M., Manfredini S., Radice M. \& Bruni R. (2005) Comparative evaluation of 11 essential oils of different origin as functional antioxidants, antiradicals and antimicrobials in foods. Food Chemistry, 91, 621-632.

Sallam K.I. (2007) Antimicrobial and antioxidant effects of sodium acetate, sodium lactate, and sodium citrate in refrigerated sliced salmon. Food control, 18(5), 566-575.

Simeonidou S., Govaris A. \& Vareltzis K. (1998) Quality assessment of seven Mediterranean fish species during storage on ice. Food Research International, 30, 479-484.

Sanches-Silva, A., Costa, D., Albuquerque, T.G., Buonocore, T.G., Ramos, F., Castilho, M.C., Machado, A.V. \& Costa, H. S. (2014) Trend in the use of natural antioxidants in active food packaging: a review. Food Additives and Contaminants: Part A, 31, 374-395.

Seyfzadeh M., Motalebi A., Kakoolaki S., \& Gholipour H. (2013) Chemical, microbiological and sensory evaluation of gutted kilka coated with whey protein based edible film incorporated with sodium alginate during frozen storage. Iranian Journal of Fisheries Sciences, 12(1), 140-153.

Shahbazi Y., Shavisi N. \& Mohebi E. (2016) Effects of Ziziphora clinopodioides essential oil and nisin, both separately and in combination, to extend shelf life and control Escherichia coli O157: H7 and Staphylococcus aureus in raw beef patty during refrigerated storage. Journal of Food Safety, 36(2), 227-236.

Sung S., Sin L.T., Tee T., Bee S., Rahmat A.R. \& Rahman W.A.W.A. (2014) Control of 
bacteria growth on ready-to-eat beef loaves by antimicrobial plastic packaging incorporated with garlic oil. Food Control, 39, 214-221.

Tang H., Lu A., Li L., Zhou W., Xie Z. \& Zhang L. (2013) Highly antibacterial materials constructed from silver molybdate nanoparticles immobilized in chitin matrix. Chemical Engineering Journal, 234, 124-131.

Tarkhasi A, Zakipour Rahimabadi E, Alizadeh doughikollaee E. \& Yousef Elahi M. (2016) Effect of edible coating containing pomegranate (Punica granatum) peel extract on the quality and shelf life of silver carp (Hypophthalmichthys molitrix) fillet during refrigerated storage. Fisheries Science and Technology, 5(2), 17-27. [In Persian]
Vasilatos G.C. \& Savvaidis I.N. (2013) Chitosan or rosemary oil treatments, singly or combined to increase turkey meat shelf-life. International Journal of Food Microbiology, 166, 54-58.

Vermeiren L., Devlieghere F., van Beest M., de Kruijf N. \& Debevere J. (1999) Developments in the active packaging of food. Trends in Food Science and Technology, 10, 77-86.

Wang H. (2014) Effect of dandelion polysaccharides on the retardation of the quality changes of white shrimp. International Journal of Biological Macromolecules, 68, 205-208. 


\title{
استفاده از يوششهاى خوراكى فعال ساخته شده از تركيبى از صمغ دانه شاهى و كارواكرول
}

جهت افزايش ماندكارى ميكَوى يرورشى نكَهدارى شده در يخجال

\author{
مريم كرمخانى'، سيد اميرعلى انوار ז"، مريم عطايى ' \\ ' كروه صنايع غذايى و تكنولوزى، دانشكده كشاورزى، واحد علوم و تحقيقات، دانشكاه آزاد اسلامى، تهران، ايران \\ r كروه بهداشت مواد غذايى، واحد علوم و تحقيقات، دانشخاه آزاد اسلامى، تهران، ايران
}

\section{جكيده}

هدف از اين مطالعه، ارزيابى تأثير بوشش خوراكى بر بايه صمغ دانه شاهى حاوى سطوح مختلف كارواكرول بر كيفيت ميكروبى،

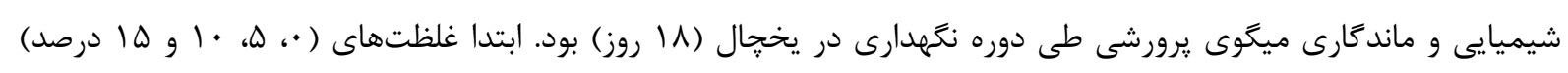
كارواكرول به يوشش افزوده و شاخصهاى رنگىى، فعاليتهاى آنتى اكسيدانى و ضدميكروبى نمونهها بررسى و سيس نمونهاى ميكو با اين محلول هاى يوششدهى و اثر آنها بر كيفيت و ماندكارى ارزيابى شد. نتايج آزمونهاى يوشش نشان داد كه با افزايش كارواكرول در يوشش خوراكى، فعاليت آنتى اكسيدانى و شاخص L* نمونهها به طور معنى دارى افزايش يافت، درحاليكه، افزودن كارواكرول به يوشش صمغ بطور معنى دارى سبب كاهش شاخص زردى شد (ه •|•>p). آناليز ميكروبى نمونهاى ميكو نشان داد يوشش خوراكى حاوى • او ها درصد كارواكرول اثر معنى دارى در كاهش بار ميكروبى داشت (ه •|•>p). استفاده از يوشش

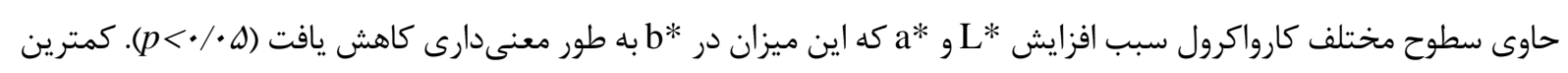
ميزان تغييرات در مقادير pH و انديس TBA در نمونههاى يوشش داده با · ا و ها درصد كارواكرول بود. نتايج بيان كرد كاربرد يوشش خوراكى غنى شده با كارواكرول به طور جشمخيرى موجب بهبود كيفيت حسى شد همجنين مشاهده كرديد كه يوشش ميكو با صمغ دانه شاهى حاوى •| و صا درصد كارواكرول، ملانوسيس در نمونهها را به تأخير انداخت. از اين رو بر اساس بررسىهاى ميكروبيولوزيكى، شيميايى و حسى، اثر يوشش صمغ دانه شاهى حاوى كارواكرول موجب حفظ كيفيت مناسب و افزايش ماندًارى طى مدت نكمدارى در شرايط سرما ترديد. ميكوى تيمار شده با يوشش صمغ حاوى • ا درصد كارواكرول را مى توان به عنوان بهترين نمونه معرفى كرد.

كلمات كليدى: ميكو، كارواكرول، صمغ دانه شاهى، يوشش خوراكى، ماندكارى، بار ميكروبى "نويسنده مسئول: saaa4824@gmail.com 